\title{
Some key sites and significant records of birds in the Philippines and Sabah
}

\author{
FRANK R. LAMBERT
}

\section{Summary}

Between June 1989 and October 1990 casual records of rare birds were made in Sabah and on Sipadan Island, Malaysia, and on Luzon, Negros, Bohol and Mindanao, Philippines, with additional observations on Palawan and Tawitawi, Philippines, in August and September 1991. Key sites for bird conservation profiled here are the Angat watershed, Quezon National Park and Candaba Marsh (all on Luzon), Mt Canlaon (Negros), Rajah Sukituna National Park (Bohol), Mt Katanglad (Mindanao), remaining forest on both Tawitawi and Sipadan, and the Danum Valley in Sabah. Notes are provided on 31 species of bird, 17 already considered threatened, three near-threatened. While one threatened species (Nicobar Pigeon Caloenas nicobarica) should be downlisted, at least six species (Spotted Imperial-pigeon Ducula carola, Blue-winged Racquet-tail Prioniturus verticalis, Blue-naped Parrot Tanygnathus lucionensis, McGregor's Cuckoo-shrike Coracina mcgregori, Falcated Wren-babbler Ptilocichla falcata and Palawan Flycatcher Ficedula platenae) should be elevated to threatened status. Records for other species supplement and reinforce current assessments of threat or indicate new distributional or taxonomic information on non-threatened forms.

\section{Introduction}

In recent years I have had the opportunity to observe some of the rarer birds of the Philippines and Malaysia. In this paper I provide a brief description of the conservation status of some important Philippine and Sabah bird sites, along with field observations of various threatened and little-known bird species and a few other range records of interest. I link this material in one paper because of the close proximity and biogeographic relationship between some of the areas mentioned. Thus the Sulu Archipelago stretches south-west from Mindanao towards mainland Sabah and Sipadan Island, Malaysia. Sibutu, at the southern end of the Sulu Archipelago, is only c. $40 \mathrm{~km}$ from Sabah. Palawan, lying on the Sunda Shelf to the west of Wallace's Line, possesses an avifauna similar to that of Sabah. There are 23 species common to Borneo and Palawan that are not found elsewhere in the Philippines, and 11 of Palawan's 15 endemic species show closer affinities to Malaysia at the generic level than they do to other parts of the Philippines (Dickinson et al. 1991).

The observations reported in this paper from Sabah were made between June 1989 and October 1990 during a period when I conducted research on the effects of selective logging on the avifauna of Danum Valley (Lambert 1990, 1992). During this period I visited Sipadan Island in late October 1989 and 
in August 1990, and the Philippines in December 1989-January 1990 (Luzon, Mindanao, Negros, Bohol). Observations from Palawan and Tawitawi were made during August and September 1991, when I conducted surveys of the Philippine Cockatoo Cacatua haematuropygia on behalf of IUCN (Lambert in press).

\section{Notes on some important bird sites in the Philippines}

\section{The Angat watershed, Luzon}

The following account derives from a five-day visit to the most accessible part of the watershed nearest the dam at Angat in 1990, and a two-day visit in 1991. The forest here lies between 250 and $520 \mathrm{~m}$. Undisturbed forest reaching over $1,000 \mathrm{~m}$ occurs on the other side of the watershed, but is off-limits to casual visitors. It could potentially hold many interesting species, such as Koch's Pitta Pitta kochi.

Many of Luzon's endemic birds occur in this watershed: probably most of the lowland species. The forest here is of low stature (compared to Sundaic forests, and forests in other parts of the Philippines), on steep slopes, very dry (at least during January 1990), and growing on what appear to be very poor soils with no humus layer. Surrounding areas are seriously degraded scrub and grassland.

Although this watershed is essential for the water and electricity supply of Manila, there is serious forest degradation in the vicinity of the dam. People living on the edge of the watershed are slowly removing many of the largest trees as well as collecting rattan. However, much of the area remains in a little disturbed state, and forest can be seen stretching far into the southern Sierra Madre. I suspect that this area needs to be carefully protected if serious future water shortages are to be avoided.

In 1990, locals were observed catching hundreds of Philippine Lorikeets Loriculus philippensis for the bird trade (using live decoys and bird-lime).

\section{Quezon National Park, Luzon}

This area is of prime importance to bird conservation. Many endemic species occur there. Some of them, such as Ashy Thrush Zoothera cinerea, Green Racquet-tail Prioniturus luconensis, Merrill's Fruit-dove Ptilinopus m. merrilli and Luzon Bleeding-heart Gallicolumba luzonica may be rare at other sites; for instance, none of these species has been recorded at Angat (T. H. Fisher verbally). Quezon suffered in the forest fires of 1983 (T. H. Fisher verbally): whole sections of forest near the peripheral road appear to be dead. Illegal logging and the collecting of forest products goes unchecked: there appeared to be no forest guards or staff stationed at the park during my visits. The forest differs from that at Angat in being of taller stature. Limestone outcrops dominate the forest on higher ridges.

\section{Candaba Marsh, Luzon}

In the past, Candaba Marsh was a very important wintering site for waterbirds, particularly ducks. In the last few years the local people have started to grow 
rice instead of watermelons in the surrounding area. This entails draining the marshes in December or January instead of March or April. As a result only a few ducks now winter at Candaba. The effect on other waterbird species is unknown. Despite this, and the eruption of Mt Pinatubo in 1991, Candaba remains a very important wetland, and its value as a conservation area now needs urgent assessment.

\section{Mt Canlaon, Negros}

The following notes are based on observations made above Mambucal in 1990. The situation on the other side of the mountain may be different. Mt Canlaon, a national park, is of critical importance for bird conservation (see Brooks et al. 1992). The endemic species that occur there are in the most threatened forest zone, between 800 and $1,250 \mathrm{~m}$.

The slopes have been cleared to about $800 \mathrm{~m}$, except in a few valleys where there are narrow galleries down to around $700 \mathrm{~m}$. Montane, mossy forest starts at around 1,700 m. In January 1990, illegal loggers were active daily between 800 and $1,250 \mathrm{~m}$. These loggers cut wood for charcoal-burning and timber. Timber is cut into c. $3 \mathrm{~m}$ rectangles (tablons) and hauled down the mountain by water buffalo. Usually only the bottom $3-8 \mathrm{~m}$ of the tree are utilized: there is a huge wastage. Large numbers of ornamental plants (orchids, ferns, palms) are collected for sale from higher altitudes. There appear to be significant numbers of people living within the park at $800-850 \mathrm{~m}$. These people have clear-felled large patches of forest. There was no sign that the forest fires of 1983 affected this side of Mt Canlaon.

\section{Mt Katanglad range, Mindanao}

I assessed the situation within the Mt Katanglad range from one side (above $\mathrm{km}$ post 1503, north of Malaybalay). The situation on the other side may be different. The overall impression gained in 1989-1990 was that much of this area would be devoid of trees within 10 years unless some drastic measures are taken to prevent further forest clearance and fires.

Mt Katanglad is probably one of the most important sites for endemic birds in Mindanao. Most of the montane endemics have been recorded here (Dickinson et al. 1991), including one species not found on Mt Apo, McGregor's Cuckoo-shrike Coracina mcgregori. In 1989-1990, a pair of Philippine Eagles Pithecophaga jefferyi were nesting in the area visited. Although the lower slopes were probably important for lowland forest bird species in the past, these slopes have been mostly cleared, with little forest surviving below $1,200 \mathrm{~m}$. Forest fires swept through parts of the mountain range in 1983: very large patches of dead (burnt) trees could be observed at some surprisingly high elevations: $1,500 \mathrm{~m}$ to the tops of the ridges (at unknown altitudes).

Forest in deep valleys extends down to $c .1,100-1,200 \mathrm{~m}$. However, between these valleys the forest has been extensively cleared for agriculture or has been burnt, in places up to $1,600 \mathrm{~m}$. Outside of valleys, much of the forest below $1,450 \mathrm{~m}$ exists as a mosaic of small disturbed patches separated by grassland and fields. In 1990, scores of impoverished farmers were growing vegetables on the poor soils up to this altitude. Presumably pressure on the forests at 
higher elevations will increase as the soils below become useless. Chainsaws were heard daily, much of the resulting timber being wasted because of the practice of using these trees to make "tablons". The outlook for forests on this side of the Katanglad range is extremely bleak.

\section{Rajah Sukituna National Park, Bohol}

This is a very important site, with many endemic Philippine species including such little-known and rare forest birds as Azure-breasted Pitta Pitta steerii, Bluecrowned Raquet-tail Prioniturus discurus, Streaked Ground-babbler Ptilocichla mindanensis, Winchell's Kingfisher Halcyon winchelli, Samar Tailorbird Orthotomus samarensis and Mindanao Bleeding-heart Gallicolumba criniger.

The reserve, $90 \mathrm{~km}^{2}$ in area (Collins et al. 1991), comprises a series of steep, often jagged, limestone outcrops surrounded by agricultural lands. There has been very successful replanting of trees in deforested areas around the edges, creating a zone of commercial timber species (although it is not clear whether these are intended to protect the watershed or be cut). Although there is some illegal tree-cutting within the reserve, this appears to be of low intensity and could probably be controlled fairly easily. Rattans and other forest products are collected from within the reserve. In 1990, there appeared to be no active management of this reserve, and no staff based at the headquarters at Logarita Forest Station, although this might in part be explained by an insurgency problem.

\section{Tawitawi, Sulu Archipelago}

The Sulu Archipelago has a total of three endemic birds, all of which occur on the $630 \mathrm{~km}^{2}$ island of Tawitawi. Two of these are considered threatened by Collar and Andrew (1988): Sulu Bleeding-heart Gallicolumba menagei and Sulu Hornbill Anthracoceros montani. Observations made during flights over Jolo and Tawitawi (the main islands of the Sulu Archipelago) in September 1991 indicated that virtually no forest remains on the former and that only the eastern half of the latter now supports any substantial forest (Lambert in press), in the order of $250-350 \mathrm{~km}^{2}$ in total area.

Illegal selective logging was occurring along the northern coast during my visit in September 1990, with trees down to around $30 \mathrm{~cm}$ diameter at breast height being cut with chainsaws. The timber was shipped to Mindanao and other parts of the Sulu Archipelago, apparently to supply the domestic market. Although the forests of Tawitawi are of very high conservation concern, the insurgency problem on the island is so serious that any efforts to save the remaining forest in the immediate future would probably be unsuccessful.

\section{Notes on some important bird sites in Sabah}

\section{Sipadan Island}

Sipadan Island is Malaysia's only true atoll, lying east of Tawau, on the east coast of Sabah. Its area is probably in the order of $1-2 \mathrm{~km}^{2}$. The island lies 
approximately on the border with Kalimantan, Indonesia, and is the subject of a dispute, partly because of its huge tourist potential. Tourist developments have proceeded since my visit in 1991: there are reported to be at least three diving companies that have built accommodation on the island for divers and staff. The island probably has few resident species, though these include Whitevented Whistler Pachycephala homereyi and Tabon Scrubfowl Megapodius cumingii, both with very restricted ranges in Malaysia. Various pigeons visit the island, including two species considered threatened by Collar and Andrew (1988): Grey Imperial-pigeon Ducula pickeringii and Nicobar Pigeon Caloenas nicobarica (see species accounts below).

Presumably Grey Imperial-pigeon and other pigeons move between islands in search of fruit. All are specialized fruit-eaters; Ducula and Ptilinopus species are important seed-dispersers rather than seed-predators (Lambert 1989) and are therefore likely to be very important to the maintenance of forests on the islands that they inhabit or visit. Whilst the colonizing abilities of these pigeons appear to be excellent, the number of forested islands on which they can find food or nest must be decreasing and the distances between such islands increasing. Forest on the islands that they inhabit was already being cleared for plantations of coconut at the beginning of this century (Riley 1930).

\section{Danum Valley}

Danum Valley, situated some $70 \mathrm{~km}$ inland from Lahad Datu, on the Segama River, consists of a $438 \mathrm{~km}^{2}$ conservation area of primary forest lying within the Ulu Segama Concession, which comprises almost a million hectares of forest under logging concession to the Sabah Foundation. Much of this area has already been selectively logged or will be logged in the future.

The vegetation at Danum Valley is Parashorea malaanonan type forest typical of the east coast of Sabah. In the area where most research has been conducted, Euphorbiaceae and Dipterocarpaceae are the dominant families of tree, with $c$. $60 \%$ and $6-7 \%$ of basal area respectively. Campbell (1990) and Lambert (1990, 1992) describe the vegetation in more detail. The terrain in the conservation area is hilly, with highest altitudes at $c .1,100 \mathrm{~m}$ and the majority of land being below $600 \mathrm{~m}$. The avifauna is very rich. During my study at Danum Valley, I recorded 186 resident species of bird in c. 33 ha of primary forest adjacent to the Segama River at $180-240 \mathrm{~m}$ altitude. Species present in the conservation area include at least nine Bornean endemics, three of which appear to be very rare in logged forests and perhaps dependent on the persistence of unlogged forest patches within the logged-forest mosaic: Black-throated Wren-babbler Napothera atrigularis, Bornean Wren-babbler Ptilocichla leucogrammica and Bornean Blue Flycatcher Cyornis superba (Lambert 1990, 1992).

\section{Species accounts}

I provide notes on the following bird species on the basis of their being judged threatened $(T)$ or near-threatened ( $n-t)$ by Collar and Andrew (1988), or otherwise because I believe their conservation status deserves such listing, or because my records represent apparently significant or noteworthy new information. 


\section{Storm's Stork Ciconia stormi (T)}

A Storm's Stork observed near Mt Silam, eastern Sabah, on 27 January 1990 was a new record for the area. The bird was feeding at a pool beside a main logging road in an area of selectively logged forest.

\section{Philippine Eagle Pithecophaga jefferyi (T)}

Philippine Eagle(s) were heard on Mt Sinako (between Mt Apo and Mt Katanglad, Mindanao) at the end of December 1990, and an abandoned nest (the tree now virtually isolated and heavily disturbed) was observed. One pair (one bird incubating on nest) was found in a deep forested valley at c. 1,350 $\mathrm{m}$ on $\mathrm{Mt}$ Katanglad on 30 December 1989.

\section{Tabon Scrubfowl Megapodius cumingii (n-t)}

The presence of Tabon Scrubfowl on Sipadan Island, Sabah, was confirmed, although the population on the island must be very small.

\section{Bulwer's Pheasant Lophura bulweri (T)}

A male Bulwer's Pheasant was observed in the Danum Valley Conservation Area, Sabah, on 26 September 1990, at the base of a steep slope at around 250$300 \mathrm{~m}$ altitude. The vocalizations heard, which may have been made by other, unobserved, individuals, could easily be passed off as a squirrel. This is the first confirmation that the species survives in this part of Sabah. The lack of previous records from so relatively well-watched an area possibly reflects a nomadic life-style. My record coincided with a synchronous mass fruiting of dipterocarps and other trees that attracted unusual numbers of bearded pigs Sus barbatus into the area.

\section{Palawan Peacock-pheasant Polyplectron emphanum (T)}

A male was observed in St Paul Subterranean National Park on 4 September 1991. It was calling in an area of steep-sided valleys in pristine rainforest close to the sea at $c .50 \mathrm{~m}$ altitude. The species was also heard in the flat valley bottom of the Babuyan river valley on the boundary of the national park.

Elsewhere, a dead female that had been snared was observed in a remnant patch of primary mixed with disturbed forest in lowlands near Megtubog. This area is situated approximately $18 \mathrm{~km}$ due west of Mount Langargun in southern Palawan. Slash-and-burn farmers in the area set snares for this species and for Red Junglefowl Gallus gallus on a daily basis and claimed to eat peacockpheasants regularly. The record is of significance since McGowan et al. (1989) were only able to trace one recent record from the south of the island: a specimen from near Quezon.

Villagers from Danlig, on the east coast of northern Palawan adjacent to Dumaran Island, reported that the Palawan Peacock-pheasant occurs in the scattered forest patches that remain in that region. According to McGowan 
et al. (1989), the occurrence of the species has not been confirmed from this far north $\left(10^{\circ} 32^{\prime} \mathrm{N}\right)$. Whilst the lowlands and hills in this part of Palawan are under intensive pressure, with most forest already largely cleared or seriously degraded, the occurrence of the peacock-pheasant at this latitude gives hope that it might occur in the Pagdanan Range to the west, where there is still considerable forest.

\section{Grey Imperial-pigeon Ducula pickeringii (T)}

Grey Imperial-pigeon is endemic to the small islands of the Sulu Sea and north Borneo. A group of about five were seen on Sipadan Island on 26 October 1989 but not on other dates during the visit, between 22 October and 31 October, despite extensive searching. This is the first confirmed sighting for the island. Other pigeons observed on Sipadan were Pied Imperial-pigeon $D$. bicolor (one group of about 12 flew in from the sea and the species was seen on most subsequent days), Metallic Wood-pigeon Columba metallica (a few observed), Nicobar Pigeon (see below) and Black-naped Fruit-dove Ptilinopus melanospila (three nests of which were found in low canopy/understorey: this species was commonly observed during the visit and on a subsequent visit in 1991).

Specialized small-island pigeons, in particular the Grey Imperial-pigeon, which has a relatively small known range, must be threatened in view of the increasing scarcity of suitable islands that they can inhabit, although the extent to which $D$. pickeringii depends on mangrove areas in mainland Borneo has never been assessed. Records from the mainland are scant (Gore 1968, Smythies 1981), but few ornithologists have worked in the extensive mangrove areas on the coast of East Kalimantan (see Collins et al. 1991), where Grey Imperialpigeon could occur. Small offshore islands adjacent to these mangrove areas supported populations of these birds in 1912 (Riley 1930). Boden Kloss (1930) reported Grey Imperial-pigeon very common on the isolated forested island of Mangalum (c. $48 \mathrm{~km}$ west-north-west from Kota Kinabalu), whilst it was abundant on Mantanani in 1886 . Its present status on these islands is unknown, though it was reported to be rare in the southern Sulu Archipelago in 19711972, the only specimen then collected being in a remnant patch of original dipterocarp forest on the small island of Sipangkot (duPont and Rabor 1973).

\section{Nicobar Pigeon Caloenas nicobarica $(\mathrm{T})$}

Five were observed together on Sipadan Island on one date between 22 October and 31 October 1989. This widespread species was treated as threatened by Collar and Andrew (1988) because of marked declines in parts of its range, and it may now be rare on Bornean offshore islands because fewer support forest. However, it is probably not uncommon in other parts of its range, where it occurs on the mainland of relatively large islands as well as on the numerous smaller islands in the Indonesian archipelago. I have, for example, observed the species inland on Halmahera and Bacan and have reliable reports from coastal Obi (Lambert and Yong 1989, Lambert in press), whilst Bowler and Taylor (1989) even found it in submontane forest on Seram. Though there can be no doubt that the species has declined in range and numbers, and is under 
considerable threat from habitat loss, hunting and trade, I would suggest that, overall, it is near-threatened rather than threatened at the present time.

\section{Spotted Imperial-pigeon Ducula carola (n-t)}

A flock of about 23 was observed in forest adjacent to the Angat Dam on 16 January 1990. This species now appears to be rare or local in the Sierra Madre mountains: Poulsen (in press) saw this species only once during four months of fieldwork in the northern Sierra Madre during 1991 and 1992.

\section{Negros Bleeding-heart Gallicolumba keayi (T)}

I had a probable sighting at between 1,150 and 1,200 $\mathrm{m}$ on Mt Canlaon (north-central Negros) in mossy forest on the afternoon of 12 January 1990. The bird was flushed from beside the main trail above Mambucal and flew only a few metres before landing on the ground again and running off: size and behaviour strongly suggested Gallicolumba. Prior to this possible sighting, the last record was of a single bird in 1927 (Brooks et al. 1992). However, Brooks et al. (1992) had one observation of this species in the same area, at $900 \mathrm{~m}$, in 1991.

\section{Sulu Bleeding-heart Gallicolumba menagei $(\mathrm{T})$}

The Sulu Bleeding-heart is known with certainty only from Tawitawi, and although there is a tentative sight record from Jolo from the beginning of this century (Dickinson et al. 1991) this latter island now appears to be devoid of forest. The species was not observed on Tawitawi during my visit in September 1991, but it is hard to imagine that it does not still occur in the extensive forests on the island. Whilst I visited what I assume was suitable habitat, my obligatory armed guards from the mayor's private army made it impossible to observe shy forest birds. It should be noted, however, that duPont and Rabor (1973) did not collect this species during their 22-day stay on Tawitawi in December 1971.

\section{Philippine Cockatoo Cacatua haematuropygia (T)}

The presence of cockatoos on two islands from which they were previously unrecorded, Dumaran and Pandanas in Palawan province, was confirmed. These islands are both important sites for this seriously threatened parrot. Six weeks of surveys for the species were conducted in August and September 1991, and a population estimate of $800-3,000$ birds was made for Palawan province (Lambert in press). The island of Pandanas, together with the adjacent islands of Bugsuk and Bancalan probably support in the order of 100-300 Philippine Cockatoos, though they are said to be visited by many bird-trappers from the mainland. Dumaran probably supports 150-250 cockatoos, though these birds may be breeding on the mainland, which is only some $3 \mathrm{~km}$ from the nearest point of the island. 


\section{Blue-winged Racquet-tail Prioniturus verticalis}

Endemic to the Philippine islands of Tawitawi, Bongao, Manuk Manka, Tumindao and Sibutu (Dickinson et al. 1991), this species was reported as abundant in mangrove on Tawitawi a hundred years ago (McGregor 1909), and occasionally observed in pairs in forested areas on Tawitawi, Sibutu and Sanga Sanga (missed from the list of islands in Dickinson et al. 1991) by duPont and Rabor (1973) in September and October 1971. During a visit to Tawitawi, small numbers were observed in forest and forest edge in the northern part of the island between 24 and 26 September 1991. A female was observed at a nest-hole in a large palm-tree with a broken top. This tree was part of a grove of palms in an agricultural area close to the forest. No Racquet-tails were observed in agricultural areas away from the forest.

Habitat loss must be a serious threat to this species and is exacerbated by the human use of large birds, including racquet-tails, for target practice. Many men on Tawitawi are armed with high-powered rifles, and the racquet-tails, which are very tame, make easy targets compared to warier birds such as the Sulu Hornbill. This species was not observed far away from good forest, and it should therefore be considered as threatened by forest loss. It was nowhere listed by Collar and Andrew (1988).

\section{Blue-naped Parrot Tanygnathus lucionensis}

Although widespread in the Philippines, the Blue-naped Parrot is apparently now rare throughout much of its range. For example, Brooks et al. (1992) and Evans et al. (1993) failed to observe this species during surveys on Negros and Siquijor respectively, and only two single birds at one of six sites visited on Mindoro (Dutson et al. 1992). Palawan may now be the last stronghold for this species which, outside of the Philippines, is only found on a few small islands off Sabah and on Talaud (to the north of Sulawesi) (White and Bruce 1986).

On Palawan in 1991 I regularly observed the Blue-naped Parrot in areas of secondary forest and in scattered trees within agricultural lands close to forest, but its overall status on the island must be considered as uncommon. Usually the species was found in flocks of 4-10 birds. This is one of four hole-nesting species that local tribespeople target for the pet trade, many of the birds being sold locally. Nesting trees of this and the other species (Hill Myna Gracula religiosa, Palawan Hornbill Anthracoceros marchei and Philippine Cockatoo) are purposely left standing in agricultural land so that young can be harvested from the nest. Hence trapping on Palawan threatens the long-term survival of this species. Whilst nowhere listed by Collar and Andrew (1988), I would recommend that Blue-naped Parrot be added to the threatened species list.

\section{Philippine Needletail Mearnsia picina}

One or two Philippine Needletails were observed at close range to the north of Batu-Batu, Tawitawi, on 24 September 1991. Prolonged views in good light were obtained as the bird(s) repeatedly returned to an area where numerous swiftlets were feeding at the edge of forest in agricultural land. There are no previous 
records of this species from the Sulu Archipelago, the nearest island on which it is known to occur being Mindanao (Dickinson et al. 1991).

\section{Sulu Hornbill Anthracoceros montani (T)}

This bird, endemic to the Sulu Archipelago in the southernmost Philippines, is known only from the islands of Jolo, Tawitawi and Sanga Sanga. In 1971 it was described as fairly common in the dipterocarp forests of Tawitawi (duPont and Rabor 1973). Two adults with an immature were observed in primary forest in the northern part of Tawitawi on 26 September 1991. Given Jolo's virtual deforestation, it seems likely that the last stronghold of the species is Tawitawi. However, my interviews with local people suggested that this species is shot if encountered in the forest, and considering the large number of heavily armed militias on the island, it seems very probable that hunting, for food or target practice, must be a serious threat to the species.

The immature bird had a greenish bill with pale yellowish-white tip and culmen. The area around the eye was greyish. The birds were feeding on large, lipid-rich fruits in an emergent tree believed to be a member of the Lauraceae.

\section{Azure-breasted Pitta Pitta steerii (T)}

I observed one in the Rajah Sukituna National Park, near Bilar, Bohol, in January 1990, in an area of rather stunted forest growing on jagged limestone outcrops and bedrock. During my visit I did not hear this species calling, but in late May and June it is regularly heard at this site (J. Hornskov in litt., J. Howes verbally), suggesting that breeding occurs in the middle of the year. Collar and Andrew (1988) noted that this pitta is "partial to montane forests", but Bilar is in the hills, and certainly not montane. On Samar, the species has been found from 100 to $600 \mathrm{~m}$ altitude, on Bohol from 350 to $750 \mathrm{~m}$ (Lambert and Woodcock in prep.).

Observations and collection localities of Azure-breasted Pitta all suggest that the species favours forests on karst, as suggested by Whitehead (1899). On Bohol, Azure-breasted Pittas were collected by Rand and Rabor (1960) only in areas of dark, dense primary forest in rocky limestone areas, whilst the collecting sites that they visited on Samar were also primarily in areas with jagged limestone outcrops. Recent sightings from Mindanao, like those from Bohol, are also from limestone hills ( $\mathrm{H}$. Buck in litt.).

\section{White-winged Cuckoo-shrike Coracina ostenta (T)}

Brooks et al. (1992) recorded this species on Mt Canlaon at 700-1,100 m in 1991. In January 1990, I found it to be relatively common in mixed bird flocks from the forest edge at $800-1,200 \mathrm{~m}$ on Mt Canlaon above Mambucal. It frequents the larger trees of the canopy and subcanopy. Between one and four individuals were observed in about half of the mixed-species flocks observed.

\section{McGregor's Cuckoo-shrike Coracina mcgregori (n-t)}

This bird is perhaps now restricted to Mt Katanglad, Mindanao, where it was only observed in the canopy and subcanopy of undisturbed forest in the deep 
valleys, between $c$. 1,300 and 1,500 m. Forest at this altitude is seriously threatened (see notes on Mt Katanglad); consequently this bird should now be considered at global risk of extinction.

\section{White-lored Oriole Oriolus albiloris}

This species, recognized as distinct by Sibley and Monroe (1990) but treated as the Luzon race of Philippine Oriole O. steerii by Dickinson et al. (1991), was regularly observed high in tall trees in forest and at the forest edge within the Angat watershed at c. 350-500 m. On 14 January 1990, a bird was observed building a nest at the edge of the canopy of a $c$. $40 \mathrm{~m}$ tall emergent tree. The nest was large and obvious, and appeared to have an outer covering of moss.

\section{Slender-billed Crow Corvus enca}

The endemic race pusillus is relatively common in forested areas on Palawan. It seems worthy of note that it gives a very different call to that of $C$. e. compilator of Peninsular Malaysia and Borneo, and has a significantly different flight pattern: the species would seem a very good candidate for taxonomic revision. The frog-like call of Slender-billed Crows on Palawan is never given by representatives of the species in Malaysia, with which I am very familiar, and the whirring flight with rapid, shallow flaps that is typical of birds on Palawan is also very different to the more casual flight of birds in Peninsular Malaysia and Sabah.

\section{Luzon Wren-babbler Napothera rabori (T)}

A pair was observed walking and feeding on the floor of primary forest at 250$300 \mathrm{~m}$ in the Angat watershed close to the Angat reservoir, Luzon, on 16 January 1990 . A sound-recording made at $c .450 \mathrm{~m}$ may have also been this species, although playback did not elicit a response. Elsewhere the three subspecies of this Luzon endemic are only known from a few specimens collected at six sites and from more recent field observations made in Quezon National Park and at several localities in the northern Sierra Madre mountains (Roever 1990, Dickinson et al. 1991, Poulsen in press).

The walking habit of this species, also noted by Roever (1990) in Quezon National Park and Goodman and Gonzales (1990) on Mt Isarog, is very unusual for a species of Napothera, all of whose Sundaic representatives I have observed in the field and all of which hop. It suggests to me that this species may belong in another genus.

\section{Falcated Wren-babbler Ptilocichla falcata}

In 1991, this species was noted at two sites on Palawan during brief surveys for cockatoos. One observation was made in tall primary forest in the St Paul Subterranean National Park and the other in one of the few unlogged forest patches in the lowlands of southern Palawan.

These sites were the only primary forest patches that I visited in Palawan, with the exception of a coastal strip of forest on the island of Pandanas, just 
south of Palawan. No sightings were made in areas of logged forest or secondary growth. In Sabah, the closely related Bornean Wren-babbler $P$. leucogrammica is extremely rare in selectively logged forest (Lambert 1990, 1992), and its survival might be dependent on small patches of unlogged forest within the loggedforest mosaic. It is therefore perhaps not surprising that its Palawan counterpart was only observed in unlogged forest. If Falcated Wren-babbler is indeed unable to survive in logged forests, it may prove one of the most seriously endangered of the endemic species of Palawan.

Flame-templed Babbler Stachyris speciosa (T)

On Mt Canlaon, I observed a total of five in three mixed bird parties between the forest edge at $800 \mathrm{~m}$ and $1,100 \mathrm{~m}$. Although shy, this species was judged to be uncommon compared to most birds of mixed-species flocks. It fed in dense understorey close to the ground as well as in more open understorey trees up to about $8 \mathrm{~m}$. In view of continuing forest clearance on Negros, this endemic species should certainly be considered threatened: Brooks et al. (1992) suggest that its status is Vulnerable.

\section{Brown-headed Thrush Turdus chrysolaus}

At least three, possibly many more, were observed on Mt Polis, Ifugao subprovince, Luzon, on 18-19 December 1989. These records are noteworthy since this winter visitor has only rarely been recorded in the Philippines.

\section{Mountain Leaf-warbler Phylloscopus trivirgatus benguetensis}

This was a relatively common species on Mt Polis in December 1989. The differences between these birds and those from Peninsular Malaysia and the Greater Sundas (race parvirostris) are striking. The latter are readily identified by their prominent yellow crown-stripe and lack of wing-bar. In contrast, birds in northern Luzon have no yellow crown-stripe but a single yellow wing-bar. Birds observed on Mt Canlaon, Negros (race nigrorum), also had a dark olive crown lacking a crown-stripe and some birds had a narrow yellow wing-bar. An investigation of the taxonomy of this and many of the other recognized endemic subspecies of Phylloscopus in the Philippines would almost certainly show that some taxa should be elevated to species level.

\section{Speckled Reed-warbler Acrocephalus sorghophilus (T)}

A few were observed at Candaba Marsh on 24 December 1989, but this species did not appear to be very common there. They were only observed in fairly tall, dense vegetation growing above deep water at the edges of ponds permanently enclosed by dykes.

\section{Palawan Flycatcher Ficedula platenae}

Although Ficedula flycatchers can be easily overlooked during brief surveys, observations made in September 1991 in forest areas scattered throughout Pala- 
wan suggested that this is a genuinely rare or uncommon species. It was only found at two sites during these brief surveys. One observation was made in tall primary forest in the St Paul Subterranean National Park, and the other was in one of the few unlogged forest patches in the lowlands of southern Palawan. Both sightings were of single birds low in understorey that was particularly rich in rattans and other understorey palms, perhaps suggesting some degree of habitat specialization.

As mentioned under Falcated Wren-babbler, these sites were the only primary forest patches that I visited in Palawan, with the exception of a site on Pandanas. No sightings of Palawan Flycatcher were made in areas of logged forest or secondary growth. Lowland forest flycatchers of the genus Ficedula in other parts of the Sunda region are known to be sensitive to the effects of logging (Lambert 1990, 1992), and it is therefore perhaps not surprising that this species was only observed in unlogged forest. Indeed, if it is as sensitive to logging as related Sundaic species such as the Rufous-chested Flycatcher Ficedula dumetoria appear to be, then it may be one of the most seriously endangered of the endemic species of Palawan.

The call of Palawan Flycatcher is very unusual, a high-pitched ze-ee, which often sounds like one note and is repeated about 10-15 times before the bird utters a short 4-5 second trill. The call is remarkably insect-like and could easily be mistaken as such. During calling, the bright rufous tail is fanned and slowly wagged up and down.

\section{White-vented Whistler Pachycephala homereyi}

Whistlers were common on Sipadan Island, Sabah. The birds were identified as White-vented, presumably of the nominate race, which is distributed through the Sulu Islands, but in Malaysian waters has previously been identified only on the island of Pulau Siamil, which is also east of Tawau (Dickinson et al. 1991). The assertion by Dickinson et al. (1991) that this species is endemic to the Philippines is evidently incorrect.

\section{Celestial Monarch Hypothymis coelestis (T)}

A pair was observed in a mixed bird flock at 250-300 $\mathrm{m}$ in the Angat watershed on 16 January 1990, less than $1 \mathrm{~km}$ from the Angat reservoir. The birds were feeding in the subcanopy of small trees at between 5-8 m above the ground in little-disturbed forest on a steep slope. Other species in the flock were Blacknaped Monarch $H$. azurea, Blue-headed Fantail Rhipidura cyaniceps, Stripeheaded Rhabdornis Rhabdornis mystacalis, Sulphur-billed Nuthatch Sitta frontalis oenochlamys, Yellow-bellied Whistler Pachycephala philippinensis and Lemonthroated Leaf-warbler Phylloscopus cebuensis. Dickinson et al. (1990) reported that, on Luzon, the Celestial Monarch probably occurs only in Bataan, but my record, from the eastern hills that are contiguous with the forested Sierra Madre mountains to the north, suggested that this inexplicably rare and poorly known species might yet be found in other parts of Luzon; and indeed it has (Poulsen in press). 


\section{Scarlet-backed Flowerpecker Dicaeum cruentatum}

A singing male Scarlet-backed Flowerpecker seen on the coast near Tawau on 21 October 1989 had a scarlet crown and rump but black back, and is perhaps an undescribed race since the back is normally scarlet.

\section{Mindanao Parrotfinch Erythrura coloria (T)}

Two were observed on Mt Katanglad at c. 1,450-1,500 m in early January 1990 in areas of long, man-made grassland adjacent to seriously degraded forest.

\section{Discussion and conclusions}

The Philippine Archipelago, with at least 168 endemic bird species and numerous endemic subspecies, is clearly a most important country for bird and biodiversity conservation. Whilst neighbouring Indonesia has more endemics, and more species that have been identified as threatened - Collar and Andrew (1988) listed 42 threatened species from the Philippines and 126 from Indonesia - the degree of threat to a substantial number of species endemic to the Philippines is far more critical. It is clear, from my various visits to both the Philippines and most parts of Indonesia, that many of the species that are thought to be at risk in Indonesia are in fact relatively secure. In stark contrast, many Philippine endemics are now highly threatened.

Despite this, it is my impression that Indonesia now receives far more interest and investment from the conservation movement than the Philippines. As noted by Collins et al. (1991), the conservation management of virtually all existing reserves in the Philippines is weak, with many people settled in reserves and active illegal logging and clearance for agriculture in protected areas. In the Philippines, time is rapidly running out for many of those species that have very restricted ranges within the archipelago or are dependent on forests, and it is essential that a major investment in conservation of important sites urgently takes place.

My limited observations suggest that some protected areas in the Philippines, such as the Rajah Sukituna Natonal Park, Bohol, and the watershed of the Angat Dam, Luzon, though not actively managed, are not in urgent need of attention. In contrast, other important sites in the Philippines, most notably Mt Katanglad on Mindanao and Mt Canlaon on Negros, are in urgent need of active measures to protect them from the irreversible damage that is occurring daily, as trees are removed and, in many cases, fires started. The situation at these sites can only be described as critical from the point of view of conservation. If the biodiversity of these regions is to be preserved, it will be necessary to identify further sites that are now critically important and critically threatened and to prioritorize these sites for immediate conservation action. Mt Katanglad and Mt Canlaon fall into the highest category for attention.

In contrast to the Philippines, Borneo still has a vast area of forest. In 1989, Sabah, with the richest avifauna in Borneo, had an estimated 4.7 million ha of forests, of which around 2.7 million ha have now been exploited. Only 229,510 ha of Sabah's forests have been designated as virgin forest reserve 
(Sabah Forestry Department 1989). Production forest is, in theory at least, subject to selective logging on a 25 to 40 year cycle. However, extraction levels in East Malaysia (Sabah and Sarawak) are now so high that it is questionable that selective logging is sustainable (Nectoux and Kuroda 1989, Johns 1989b). For instance, extraction levels in the $9,728 \mathrm{~km}^{2}$ Ulu Segama Concession Area, Sabah, are between 90 and $120 \mathrm{~m}^{3} / \mathrm{ha}$, which compares with $8.4 \mathrm{~m}^{3} / \mathrm{ha}$ and $13.5 \mathrm{~m}^{3} / \mathrm{ha}$ in Neotropical and African forests respectively (Johns 1989b).

Hence, whilst there is still very extensive forest in Sabah, most of it will eventually be logged. It is, therefore, of utmost importance that areas such as Danum Valley, presently well protected, remain as such. Although it is apparent that the majority of bird species are able to survive in logged forests in the Sunda region (Johns 1986, 1989a, Lambert 1990, 1992), it remains unknown how much this phenomenon depends on the persistence of large primary forest patches acting as refuges and sources; and in any case, it is equally apparent that a minority of bird species will certainly become extinct in the absence of such patches.

Although large areas of selectively logged forest are of important value to bird conservation, they are unfortunately particularly susceptible to serious forest fires. At least 4.5 million ha of forest were burnt in Borneo in 1982-1983: in Sabah, $85 \%$ of the million ha burned were logged-over forests (Beaman et al. 1985). Nothing is known about the survivorship of birds in forests which have been both logged and burned, but judging by the very seriously degraded state of such areas (Woods 1989, pers. obs.), it seems probable that species which decline severely in logged forests may disappear entirely after serious drought and associated fires. Thus although most species can survive the effects of selective logging, these areas should not be considered as alternatives to reserves of primary forest areas for bird conservation. I repeat: it is essential that areas such as the Danum Valley Conservation Area are preserved as primary forest, and not subjected to logging in the future.

Whilst there is still adequate forest on the mainland of Sabah, forest on small offshore islands is very vulnerable to exploitation and is consequently becoming rather rare. The protection of remaining small, forested islands such as Sipadan may be essential if viable populations of species like the Grey Imperial-pigeon are to survive in the long term. The Malaysian government has long recognized the importance of protecting Sipadan, in part because of its use by hundreds of breeding green turtles Chelonia mydas and its possession of undisturbed coral reefs. However, because of the continuing territorial dispute with Indonesia the formal gazettement of the island as a reserve has proved problematic. If it is, eventually, given protected area status, it will be important to recognize that the whole island, and not just the beaches and coral reefs, are of great conservation importance.

\section{Acknowledgements}

My visits to Palawan and the Sulu Archipelago were made under the auspices of IUCN the World Conservation Union, on behalf of the Trade Specialist Group of the Species Survival Commission, and were greatly enhanced by assistance from the Protected Area and Wildlife Bureau in the Department of Environment and Natural Resources of the 
Philippines, the Haribon Foundation in Palawan, and staff of the St Paul Subterranean Park. Prof. and Mrs Ramero of the Mindanao State University were most helpful in providing assistance in arranging my visit to Tawitawi. I am also most grateful to Mayor Sadikul Sahali of Batu-Batu, Tawitawi, for providing me with essential protection in the form of five members of his private army, without whom I would have apparently been shot during my visit to the northern part of Tawitawi. I am particularly indebted to Tim Fisher for his invaluable advice and hospitality during both my visits to the Philippines, and to Tim Inskipp for assistance in tracking down obscure references. The Royal Society, Natural Environment Research Council and the Frank M. Chapman Memorial Fund supported my research at Danum Valley. I would also like to thank the Socio-economic Unit of the Prime Minister's Department, the Danum Valley Management Committee and Sabah Foundation, for permission to conduct research in Sabah.

\section{References}

Beaman, R. S., Beaman, J. H., Marsh, C. J. and Woods, P. W. (1985) Drought and forest fires in Sabah in 1983. Sabah Soc. J. 8: 10-30.

Boden Kloss, C. (1930) The birds of Mangalum and Mantanani Islands off the west coast of British North Borneo. Bull. Raffles Mus. 4: 117-123.

Bowler, J. and Taylor, J. (1989) An annotated checklist of the birds of Manusela National

Park, Seram (birds recorded on the Operation Raleigh Expedition). Kukila 4: 3-29.

Brooks, T. M., Evans, T. D., Dutson, G. C. L., Anderson, G. Q. A., Asane, D. C., Timmins, R. J. and Toledo, A. G. (1992) The conservation status of birds of Negros, Philippines. Bird Conserv. Internatn. 2: 273-302.

Campbell, E. J. F. (1990) Ecological relationships between lianes and trees in a lowland tropical rain forest in Sabah, Malaysia. MSc thesis, University of Stirling.

Collins, N. M., Sayer, J. A. and Whitmore, T. C., eds. (1991) The conservation atlas of tropical forests: Asia and the Pacific. London: Macmillan.

Dickinson, E. C., Kennedy, R. S. and Parkes, K. C. (1991) The birds of the Philippines. Tring, U.K.: British Ornithologist's Union (Check-list 12).

Dutson, G. C. L., Evans, T. D., Brooks, T. M., Asane, D. C., Timmins, R. J. and Toledo, A. G. (1992) Conservation status of birds of Mindoro, Philippines. Bird Conserv. Internatn. 2: 303-325.

DuPont, J. E. and Rabor, D. S. (1973) South Sulu archipelago birds. Nemouria 9: 1-63.

Evans, T. D., Magsalay, P., Dutson, G. C. L. and Brooks, T. M. (1993) The conservation status of the forest birds of Siquijor, Philippines. Forktail 8: 89-96.

Everett, A. (1887) [Letters, extracts, notices.] Ibis (5)6: 282-283.

Goodman, S. M. and Gonzales P. C. (1970) The birds of Mt Isarog National Park, southern Luzon, Philippines, with particular reference to altitudinal distribution. Fieldiana Zool. (Ser. 6o) 1415: 1-39.

Gore, M. E. J. (1968) A check-list of the birds of Sabah, Borneo. Ibis 110: 165-196.

Johns, A. D. (1986) Effects of selective logging on the ecological organisation of a peninsular Malaysian rain forest avifauna. Forktail 1: 65-79.

Johns, A. D. (1989a) Recovery of a peninsular Malaysian rainforest avifauna following selective timber logging: the first twelve years. Forktail 4: 89-105.

Johns, A. D. (1989b) Timber, the environment and wildlife in Malaysian rain forests. University of Aberdeen: Institute of South-East Asian Biology (unpublished report).

Lambert, F. R. (1989) Pigeons as seed predators and dispersers of figs in a Malaysian lowland forest. Ibis 131: 521-530.

Lambert, F. R. (1990) Avifaunal changes following selective logging of a north Bornean rain forest. University of Aberdeen: Institute of Tropical Biology (unpublished report 
to the Danum Valley Management Committee and the Socio-economic Research Unit of the Prime Minister's Department).

Lambert, F. R. (1992) The consequences of selective logging for Bornean lowland forest birds. Phil. Trans. R. Soc. London. B 335: 443-347.

Lambert, F. R. (in press) Notes on the avifauna of Bacan, Kasiruta and Obi, north Moluccas. Kukila.

Lambert, F. R. and Woodcock, M. (in prep.) The pittas, broadbills and asities of the world.

Lambert, F. R. and Yong, D. (1989) Some recent bird observations from Halmahera. Kukila 4: 30-33.

McGowan, P. J. K., Hartley, I. R. and Girdler, R. P. (1989) The Palawan Peacock Pheasant: habitat and pressures. J. World Pheasant Assoc. 14: 80-99.

Nectoux, F. and Kuroda, Y. (1989) Timber from the South Seas: an analysis of Japan's tropical timber trade and its environmental impact. Gland, Switzerland: WWF International.

Poulsen, M. K. (in press) The status and conservation of threatened birds in the Sierra Madre mountains, northern Luzon, the Philippines. Bird Conserv. Internatn.

Rand, A. L. and Gilliard E. T. (1967) Handbook of New Guinea birds. London: Weidenfield and Nicolson.

Rand, A. L. and Rabor, D. S. (1960) Birds of the Philippine Islands: Siquijor, Mount Malindang, Bohol, and Samar. Fieldiana Zool. 35(7): 225-441.

Riley, J. H. (1930) Birds from the small islands off the north-east coast of Dutch Borneo. Proc. U.S. Natn. Mus. 77: 1-23.

de Roever, J. (1990) Notes on the Luzon Wren-babbler. Bull. Oriental Bird Club 12: 33-34.

Sabah Forestry Department (1989) Forestry in Sabah. Sandakan: Sabah Forestry Department.

Smythies, B. E. (1981) The birds of Borneo. Kuala Lumpur: Sabah Society and the Malayan Nature Society.

Whitehead, J. (1899) Field notes on birds collected in the Philippine Islands in 1893-6. Ibis (7) 5: 81-111, 210-246, 381-399, 485-501.

Woods, P. (1989) Effects of logging, drought, and fire on structure and composition of tropical forests in Sabah, Malaysia. Biotropica 21: 290-298.

FRANK R. LAMBERT

IUCN Species Survival Commission, 219 Huntingdon Road, Cambridge CB3 oDL, U.K. 